\title{
Maritime Command-Language: Understanding Its Role in the Global Seafaring Profession among Maritime Youth in the Philippines
}

\author{
Rolando A. Alimen ${ }^{1}$, Engr. Cicero D. Ortizo ${ }^{2}$ and Ma. Cecilia D. Alimen ${ }^{3}$ \\ 1\&2. John B. Lacson Foundation Maritime University-Molo, Iloilo City, Philippines \\ 3.University of San Agustin, Iloilo City, Philippines
}

\begin{abstract}
In this study, the researchers categorized the different maritime command-language (words and expressions) used on-board by young Filipino officers and seafarers employed at the different foreign shipping companies in the country and abroad. The paper also ascertained the importance of maritime language in the global seafaring profession of maritime youth in the Philippines. The respondents of the present study were the young officers and seafarers of the maritime university, specifically, John B. Lacson Foundation Maritime University-Molo, Iloilo City, Philippines. Quantitative and qualitative mode of data collection was employed by the researchers. A researcher-made data gathering instrument was used to capture the necessary data in understanding the role of maritime language in the global seafaring profession. Sample utterances were gathered from the respondents and were subject to corresponding statistical interpretation. Qualitative information, comments, and remarks were utilized in this study to showcase the importance of maritime language in the profession of young officers and seafarers as graduates of leading global supplier in the international maritime industry.
\end{abstract}

Key words: Maritime language, global seafaring profession, maritime youth.

\section{Introduction}

English is the first language of the overwhelming majority of the population, as well as countries where English is one of the "official languages" such as India, and many of the African States. It is used for specific purpose such as business, commerce, work, and academic expression. While in the specialized community, the primary determinants of linguistic behavior are functional rather than social function. This is very much true with regards to mariners/seafarers, as noted by one of them:

"The seaman thus, learned a language of 'technical necessity,' a language remarkable for its 'terseness and accuracy”” (Reiner \& Parry, 1989 in Isserlis, 2008).

"English as the world leading international language

Corresponding author: Rolando A. Alimen, $\mathrm{PhD}$, Specialization: Maritime Education, Marine Environment, and Marine Engineering is the key to social, economic, and educational opportunities in our society. But Filipino workers nowadays are fast losing their global competitiveness over other nationalities due to their deteriorating English communication skills” (Gallaron, 2008).

Language is considered as important medium of communication on-board. But oftentimes, communication is badly understood because of language use, which sometimes may cause some accidents at sea. As one of the sailors commented that:

"Sailors' talk is a dialect from ordinary English as is Lowland Scotch. Certainly, English words are used, but their signification is many times remote from meaning they have in shore parlance. The meaning of many sea-phrases is too subtle for translation; some fit vocational conditions so accurately, that any divergence from the exact expression would puzzle a seaman exceedingly” (Isserlis, 2008).

Since most of the Filipino seafarers are employed on 

Maritime Youth in the Philippines

international ships, sea language is considered as essential element to warrant understanding, simultaneous ship operation, and accurate transmission of order and information.

"Maritime English is a form of communication within maritime situation. It contains special vocabulary and technical terminologies relevant to ships, their routine operations, and interaction within the international shipping industry which determines communication at sea” (Francisco \& Patricio, 2003).

The use of maritime command-language is very relevant since the world's shipping industry is composed of seafarers from different groups and nationalities. Each group may use its own first language, but, if "maritime language" should be applied, international vocabularies and terminologies would allow understanding among seafarers on-board on mixed-crewing to ensure understanding and communication with different stations.

\section{Conceptual Framework of the Study}

The present study was anchored on the conceptual framework below.

The interconnections among the four variables in the present study were shown in Fig. 1. The conceptual framework illustrated in this study means that the maritime youth on-board international shipping vessels had equipped themselves with maritime language. Furthermore, the youth of the Philippines as young officers and respondents of this study had acquired better understanding of the role of maritime language in order to become successful and competent in attaining global seafaring standards and quality.

\section{Statement of the Study}

The study determined the different maritime command-languages (words and expressions/utterances) used on-board by young Filipino officers and seafarers employed at the different foreign shipping companies in the country and abroad. The present study also ascertained the importance of maritime language in the global seafaring profession of maritime youth in the Philippines. To understand the study clearly, the following questions were advanced:

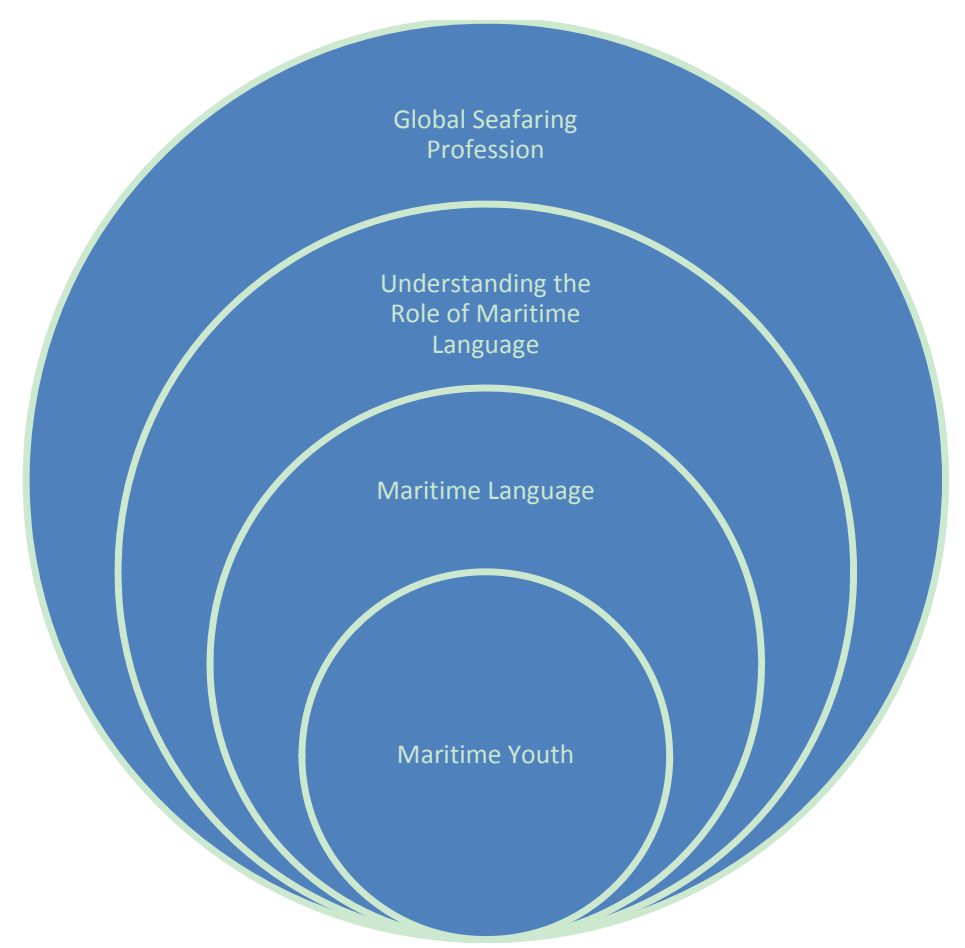

Fig. 1 Conceptual framework of the present study. 
(1) What are the most prevalent maritime command-languages used by the young seafarers on-board the international vessels as a whole, and in terms of engine orders and bow thruster's orders?

(2) What are the least prevalent maritime command-languages used by the young seafarers on-board the international vessels as a whole, and in terms of engine orders and bow thruster's orders?

(3) What are the most prevalent engine orders used by the young seafarers on-board the international vessels as a whole, and in terms of engine orders and bow thruster's orders?

(4) What are the least prevalent engine orders used by the young seafarers on-board the international vessels as a whole, and in terms of engine orders and bow thruster's orders?

(5) What is the role of the maritime language in the global seafaring profession of young seafarers in the Philippines?

\section{Methodology}

The respondents of the present study were the 56 young officers and seafarers of the maritime university, specifically, John B. Lacson Foundation Maritime University-Molo, Iloilo City, Philippines. Quantitative and qualitative mode of data collection was employed by the researchers. Researcher-made data gathering instrument was used to capture the necessary data in understanding and role of maritime language in the global seafaring profession. This instrument entitled "Role of Maritime Language in the Global Seafaring Profession Among Young Seafarers in the Philippines” consisted of the following: (a) personal data of the respondents, (b) checklist indicating the different maritime languages used on-board, and (c) qualitative section, an open-ended question, which was used to capture the role of the maritime language in the life of young seafarers at sea.

Sample utterances were gathered from the respondents and were subject to corresponding statistical interpretation. Qualitative information, comments, and remarks were utilized in this study to showcase the importance of maritime language in the profession of young officers and seafarers as graduates of leading global supplier in the international maritime industry.

The distribution of the respondents was shown in Table 1, number of months experienced by the respondents was reflected in Table 2 , names of the shipping companies and principals of the respondents was shown in Table 3, and nationalities that the respondents were working with was presented in Table 4.

Table 1 Distribution of the respondents according to the age.

\begin{tabular}{llll}
\hline Age & Frequency & Percentage & Rank \\
\hline 19 years old & 26 & 46 & 1 \\
20 years old & 14 & 25 & 2 \\
21 years old & 7 & 13 & 3 \\
18 years old & 4 & 7 & 4 \\
22 years old & 3 & 5 & 5 \\
23 years old & 1 & 2 & 6.5 \\
24 years old & 1 & 2 & 6.5 \\
\hline
\end{tabular}

Table 2 Number of months experienced by the respondents.

\begin{tabular}{llll}
\hline Month & Frequency & Percentage & Rank \\
\hline 11 months & 32 & 57.0 & 1 \\
12 months & 18 & 32.0 & 2 \\
10 months & 4 & 7.0 & 3 \\
9 months & 1 & 2.0 & 4.5 \\
8 months & 1 & 2.0 & 4.5 \\
\hline
\end{tabular}



Maritime Youth in the Philippines

Table 3 Names of shipping companies and principals of the respondents.

\begin{tabular}{lll}
\hline & Name of shipping company & Name of principal \\
\hline 1 & Wilhelmsen Smith Bell Manning & Wilhelmsen Ship Management \\
2 & GRIEG Philippines, Inc. & GRIEG Shipping Group \\
3 & Thome Ship Management (TSM) & Thome Ship Management (TSM) \\
4 & Eagle Clarc Shipping Inc. & Marinvest \\
5 & Stolt-Nielsen Philippines, Inc. & Knutsen Oas Shipping \\
6 & Medbulk & Ancora Investment Trust \\
7 & Rickmers & Global Management LTD \\
8 & K-Line & \\
\hline
\end{tabular}

Table 4 Nationalities that respondents were working with on-board.

\begin{tabular}{ll}
\hline Category & Type of Nationalities \\
\hline 1 & Polish \\
2 & Indian \\
3 & Norwegian \\
4 & Romanian \\
5 & German \\
6 & Belgian \\
7 & Croatian \\
8 & Slovenian \\
9 & British \\
10 & Russian \\
11 & Latvian \\
12 & Swedish \\
13 & Ukrainian \\
14 & Chinese \\
15 & Italian \\
16 & Venezuelan \\
17 & Sri Lankan \\
18 & Greeks \\
19 & Bulgarian \\
20 & Vietnamese \\
21 & Japanese \\
\hline
\end{tabular}

\section{Results and Discussion}

The most prevalent maritime languages or phrases used by the young seafarers in this study are the following: (1) log/log book, (2) jump ship, (3) off and on, (4) leeway, and (5) in the lee of/to leeward. However, the least prevalent languages or phrases used on-board by the seafarers are the following; (1) devil to pay, clean slate, between the devil and the deep blue sea, (2) taken the back and fits the bill. The data are shown in Table 5. Other languages or phrases used on board as mentioned in this study are: (1) slack all the line, (2) pilot on board, (3) pilot ladder secured, (4) commence of sea passage end of sea passage, (5) engine side, (6) jibs out, (7) passing clearance, (8) stand-by stations forward and aft, (9) barge away, and (10) barge alongside.

As to the engine orders, the most prevalent languages or phrases used by the young officers on-board are the following: (1) stand by engine, (2) finished with engines, (3) full ahead, (4) dead slow ahead, (5) stop engine/engines. On the other hand, the least prevalent languages used are: (emergency full ahead/astern, (2) full astern, (3) slow ahead, (4) half astern, and (5) dead slow astern. The data are shown in Table 6. The other words/languages/phrases are: (1) 
Table 5 Maritime command-languages or phrases used by the young officers on-board.

\begin{tabular}{|c|c|c|}
\hline Language/phrase used on-board & Frequency & Rank \\
\hline "Log/Log book" & 56 & 1 \\
\hline “jump ship” & 54 & 2 \\
\hline "off and on" & 36 & 3 \\
\hline “leeway” & 33 & 4 \\
\hline “"'in the lee of/to leeward” & 26 & 5 \\
\hline "Run a ground" & 25 & 6 \\
\hline “a loof” & 14 & 7 \\
\hline "all at sea” & 13 & 8 \\
\hline "bitter end" & 10 & 9 \\
\hline "too close to the wind" & 9 & 10 \\
\hline “cock up” & 5 & 11 \\
\hline "batten down the hatches" & 3 & 12.5 \\
\hline “over a barrel’ & 3 & 12.5 \\
\hline "fits the bill" & 2 & 14.5 \\
\hline "taken a back" & 2 & 14.5 \\
\hline "between the devil and deep blue sea" & 1 & 17 \\
\hline “clean slate” & 1 & 17 \\
\hline “devil to pay” & 1 & 17 \\
\hline "at loggerhead" & 0 & 20 \\
\hline
\end{tabular}

Table 6 Standard engine orders.

\begin{tabular}{lll}
\hline Language or phrase & Frequency & Rank \\
\hline "Stand by engine" & 56 & 1.5 \\
"finished with engines" & 56 & 1.5 \\
"full ahead" & 55 & 5 \\
"dead slow ahead" & 55 & 5 \\
"stop engine/engines" & 55 & 5 \\
"dead slow astern" & 55 & 5 \\
"half astern" & 55 & 5 \\
"slow ahead" & 54 & 8.5 \\
"full astern" & 54 & 8.5 \\
"emergency full ahead/astern & 45 & 10 \\
\hline
\end{tabular}

Table 7 Bow thrusters orders.

\begin{tabular}{lll}
\hline Language or phrase & Frequency & Rank \\
\hline "bow thrust full (half) to port” & 43 & 1.5 \\
"bow thrust full (half) to starboard” & 43 & 1.5 \\
"bow (stern) thrust stop” & 36 & 3 \\
"stern thrust (half) to port & 30 & 4 \\
"stern thrust (half) to starboard” & 31 & 5 \\
\hline
\end{tabular}

One hour notice, (2) short notice, (3) end of sea passage, (4) blow through, (5) Commence of sea passage, (6) Pilot onboard, (7) Pilot off, (8) Run-up, (9) Stand by, (10) Emergency maneuver, (11) Station forward and aft, (12) Rest of bunker, (13) 1,2,3, (14) Generator connected/engaged/on-board, and (15) Shaft generator (on/off).

The other terms used by the young Filipino officers are the following: (1) One-hour notice, (2) Short notice, (3) End of sea passage, (4) Blow through, (5) Commence of sea passage, (6) Pilot onboard, (7) Pilot off, (8) Run-up, (9) Stand by, (10) Emergency maneuver, 

Maritime Youth in the Philippines

(11) Station forward and aft, (12) Rest of bunker, (13) 1,2,3, (14) Generator connected/engaged/on-board, and (15) Shaft generator (on/off).

Based on the interviews and information gathered by the researchers, the young Filipino officers used other maritime languages such as the following: (1) thrusters on stand-by, (2) $50 \%$ thrusters to the port, (3) $100 \%$ thrusters to the port, (4) 50\% thrusters to the stand-by, (5) $100 \%$ thrusters to the stand-by, (6) thruster ready, and (7) finish with thruster.

\begin{tabular}{ll}
\hline As a young officer/seafarer, is understanding of maritime language important in your profession? & Frequency \\
\hline Yes & 100 \\
No & 0 \\
\hline
\end{tabular}

Table 8 Responses to the interview question.

\begin{tabular}{lcc}
\hline Responses to the question "why maritime language is important” & Frequency & Rank \\
\hline $\begin{array}{l}\text { Knowledge of maritime language facilitates communication, helps avoid accidents brought about by } \\
\text { miscommunication. }\end{array}$ & 58 \\
$\begin{array}{l}\text { Maritime language is important in my profession because this is the most common language used on board } \\
\text { the ship. It makes job orders easier to understand and to comply. }\end{array}$ & 17 \\
$\begin{array}{l}\text { Maritime language in our profession helps assure safety of our lives at sea and also for the safe operation of } \\
\text { the ship. It is vital in the daily operation on board in order to maintain safety and smooth operation. }\end{array}$ & 2 \\
$\begin{array}{l}\text { To be familiar with the words and phrases utilized on board to facilitate technical and operational functions. 8 } \\
\text { It fosters good relationship with other crew and interpersonal interaction with one another. }\end{array}$ & 2 & 4 \\
\hline
\end{tabular}

Understanding maritime command-language is important based on the seafarers' responses. All who were interviewed indicated that it is indeed relevant to put to mind the utterances used at sea. The qualitative data were analyzed using categorization method. The contents of the responses have been categorized by the researcher, who manually reviewed the documents and group those that go together. Results show that "knowledge of maritime language facilitates communication, helps avoid accidents brought about by miscommunication" ranked first with majority of the responses. The second reason was, "maritime language is important in my profession because this is the most common language used on board the ship. It makes job orders easier to understand and to comply.” This ranked second. This is followed by "maritime language in our profession helps assure safety of our lives at sea and also for the safe operation of the ship". It is vital in the daily operation on board in order to maintain safety and smooth operation ranked third. The fourth was "to be familiar with the words and phrases utilized on board to facilitate technical and operational functions." Finally, "it fosters good relationship with other crew and interpersonal interaction with one another” ranked fifth. Table 8 has the data.

\section{Conclusions}

Communication is an essential part of human interaction. The benefits of effective communication are many and obvious as they enhance all aspects of our personal and professional lives. Ineffective or misunderstood communications in our personal lives may give rise to problems or embarrassment but in our professional lives the results of misunderstandings may have much more serious results. In the world of international shipping, with seafarers from many countries sailing on ships trading to all parts of the world, effective communication between those on board and between ship and shore is vitally important (STCW and Human Element Section International Maritime Organization, 2002).

After collecting the data and questionnaires, the results of this study reveal the following:(1) seafarers use technical terms that are exclusively used on board and must be understood by Filipino seafarers to carry out their work efficiently and to avoid accidents brought about by miscommunication; (2) as an international language, English is viewed as the language understood by majority of the seafarers. Although, they were saying that sign language can also 


\section{Maritime Youth in the Philippines}

aid in cases where English becomes a difficulty; (3) there are a number of terms that are prevalent in use and there are terms that are sparingly used on board among the seafarers; (4) there are likewise prevalent and less prevalent language used as to engine orders; (5) seafarers consider the importance of maritime language on board to help facilitate communication and to avoid accidents brought about by miscommunication.

\section{Recommendations}

Dr Rick Jolly said: “The beauty of maritime command-language, just like all language, is that it is constantly evolving. Shaped by changing times and technologies, the expressions used often carry that classic mariner sense of humor. Thus, the following recommendations are advanced:

(1) Projects like this are vital in preserving the significance and awareness of maritime language and hearing from today's seafarers who may have their own 'first rate' suggestions or may really 'know the ropes' when it comes to modern-day sailor speak!” (www.royalalfredseafarers.com).
(2) If actual immersion can be done, it is better to record all communicative instances on board to assure accuracy and authenticity of data.

(3) Related studies be conducted on the relevance of maritime language in some other settings.

\section{References}

[1] Bakr, M. A. 2002. "Maritime Language: Quest for Simplicity." Maritime Policy \& Management 5 (2): 133-140.

[2] Blakey, T. N. 1987. English for Maritime Studies. United Kingdom: Prentice Hall International

[3] Francisco, E., and Patricion, L. 2003. Maritime English. John B. Lacson Foundation Maritime University and ALG \& Associates Research \& Development Corporation.

[4] Gallaron, J. B. 2008. "Dominant Approaches in Teaching English as a Second Language.” Liceo Journal Higher Education Research 5 (2).

[5] Isserlis, S. J. 2008. "The Language of the Sea: A Corpus Driven Examination of the Influence of Britain's Maritime Tradition on Standard English.” Master's thesis, University of Birmingham. GB.

[6] STCW Human Element Section International Maritime Organization (2002)

[7] www.royalalfredseafarers.com

[8] Velez, C. R. 2003. Maritime English, Quezon City: Great Books Trading. 